\title{
ENTREPRENEURIAL INTENTIONS OF STUDENTS OF HIGHER VOCATIONAL SCHOOLS ON THE TERRITORY OF AUTONOMUS PROVINCE OF VOJVODINA
}

\author{
Slobodanka Jovin* \\ Novi Sad School of Business, Novi Sad, Serbia \\ Ivana Jošanov - Vrgović \\ Novi Sad School of Business, Novi Sad, Serbia
}

\begin{abstract}
Entrepreneurship is the most important development potential of a modern economy. Students and their entrepreneurial intentions encourage the creation of an entrepreneurial society, employment growth and innovation. In order to stimulate innovation, it is necessary to improve the quality of cooperation between the economy and scientific research institutions in which young people's entrepreneurship and their innovation play an important role. In this paper, 442 students of higher vocational schools from the territory of AP Vojvodina were empirically examined. The results have pointed to the existence of the desire and intention of students to start and run their business, and that most students want to start up their own business in the future. The results have also shown that students believe that the planned time between completing studies and setting up their own work is from 3 to 5 years.
\end{abstract}

Key words: entrepreneurship, entrepreneurial intentions, innovations, influence, students, vocational schools, education

Jel Classification: $A 20$

\section{PREDUZETNIČKE NAMERE STUDENATA VISOKIH STRUKOVNIH ŠKOLA NA TERITORIJI AP VOJVODINE}

Sažetak: Preduzetništvo predstavlja najvažniji razvojni potencijal moderne ekonomije. Studenti i njihove preduzetničke namere podstiču stvaranje preduzetničkog društva, rast

\footnotetext{
*boba_jovin@yahoo.com
} 
zaposlenosti i inovativnosti. Da bi se podstakle inovacije, neophodno je da se unapredi kvalitet saradnje privrede $i$ naučnoistraživačkih institucija, u čemu preduzetništvo mladih $i$ njihova inovativnost imaju značajnu ulogu. U radu je izvršeno empirijsko ispitivanje 442 studenta visokih strukovnih škola sa teritorije AP Vojvodine. Rezultati su ukazali na postojanje želje i namera studenata da započnu i vode svoj posao, kao $i$ da najveći broj studenata želi da u budućnosti otvori svoju firmu. Rezultati su takođe pokazali $i$ da studenti smatraju da je planirano vreme između završavanja studija $i$ osnivanja vlastitog posla od 3 do 5 godina.

Ključne reči: preduzetništvo, preduzetničke namere, inovacije, uticaj, studenti, visoke strukovne škole, obrazovanje

\section{INTRODUCTION}

Entrepreneurs represent the main driver of the development of an economy. They encourage employment, growth in imports and exports, GDP growth, but also innovation. The small and medium enterprises and entrepreneurship (SMEE) sector in the European Union employs about $67.5 \%$ of the population and generates $57.5 \%$ of the value added (Eurostat, 2018).

The small and medium enterprises and entrepreneurship (SMEE) sector plays a leading role in the development of the economy of the Republic of Serbia. This sector participates with $99.8 \%$ in the total number of enterprises, employs $65 \%$ of employees, participates in total turnover with $65.4 \%$, and in gross domestic product with 34\% (Ministry of Economy, Ministry of Regional Development and Local Government, National Agency for Regional Development - NARR, 2013). These data point to the importance of the entrepreneurship sector for the economic development of Serbia.

The mere existence of a good business idea is not enough for its realization. Creating a stimulating entrepreneurial environment is the most important part of the incentive policy for the development of this vulnerable economic segment. In addition to financial support, non-financial support for the use of advisory services is equally important, while the role of continuing education is crucial.

Entrepreneurship is the main driver of innovation and economic growth. This is indicated by the recommendations of the European Union to include entrepreneurship as early as possible in the education of young people as a compulsory subject in secondary schools. Students as potential entrepreneurs represent significant strength and economic potential.

A study conducted on a sample of 304 companies in the Republic of Serbia have shown that innovations are the most represented in a group of small enterprises (Stanković, Đukić and Lepojević, 2014, 1090). 
14 | ENTREPRENEURIAL INTENTIONS OF STUDENTS OF HIGHER VOCATIOANL SCHOOLS ON THE TERRITORY OF AUTONOMUS PROVINCE OF VOJVODINA

Unemployment of young people in Serbia is a problem that can be mitigated by encouraging young people to start their entrepreneurial ventures. Research with young peoplein the Republic of Serbia has shown that young people have good business ideas, but they need more financial and institutional support for their realization. The research carried out by Jošanov-Vrgović, Jovin, PapićBlagojević and Jovičić Vuković (2017) showed that students have ideas on how to organize and launch a business venture and that these ideas if fully supported could grow into a business venture. This research has shown that the existence of space for the development of these ideas would facilitate their realization. In order to motivate students to start entrepreneurial ventures, it is necessary to invest in infrastructure, research and development as well as in continuous education. Research results of students of higher vocational schools conducted by Jovin, Papić-Blagojević, Jošanov-Vrgović and Jovičić Vuković (2018), showed that students find that lack of premises, lack of business partners, equipment and time makes it difficult for them to realize their entrepreneurial ideas. The same research has shown that young entrepreneurs need specific support programs, primarily in the form of education and advisory services, and then the development of institutional and innovation infrastructure, as well as the support of financial institutions.

Research with youth carried out by the Young People's Forum (2016) showed that $44 \%$ of young entrepreneurs have a business idea, but do not start with its realization, $22 \%$ have been being educated, have visited seminars dedicated to entrepreneurship and even have prepared a business plan, $16 \%$ of young people started the business less than 12 months ago, while $13 \%$ of respondents have already started their business.The Global Entrepreneurship Monitoring (GEM) Report (2015) forecasts that young entrepreneurs will be the drivers of change and economic growth in the future.

Bearing this in mind, the eximination of entrepreneurial potentials and the existence of entrepreneurial intentions of students of higher vocational schools on the territory of the Autonomous Province of Vojvodina was initiated. 442 students enrolled at the higher vocational schools from the territory of AP Vojvodina were examined.

\section{ENTERPRENEURIAL ATMOSPHERE IN THE REPUBLIC OF SERBIA}

Unemployment of young people in Serbia is a big problem whose resolution requires the involvement of various social actors. Youth entrepreneurship in Serbia can contribute to reducing youth unemployment. For this reason, the development of entrepreneurial awareness among young people is the first step in the development of youth entrepreneurship. Youth entrepreneurship has been 
recognized by the Ministry of Economy through the "Strategy for supporting the development of SMEE sector and competitiveness for 2015-2020" and accompanying documents.

Many studies indicate that young people in Serbia have good and creative business ideas, but they need greater support in terms of education, business conditions, business and financial support, because the path from the idea to its realization is difficult and complex, and young people generally do not have enough experiences.

According to the Global Competitiveness Report for 2017/2018 Serbia, looking at the pillar 12 which represents the overall innovation, is ranked 95th out of 137 countries surveyed. Within this pillar, the capacity for innovation has reached the lowest ranking (117th place), while the quality of scientific-research institutions is ranked the best (47th place). University-industry collaboration in $\mathrm{R} \& \mathrm{D}$ is not in a satisfactory position, that is, it is ranked 95th out of 137 countries.

Table 1 shows the observed innovation rankings for the Republic of Serbia and individual countries in the region.

Table 1

Achieved innovation rankingsin 2017/2018.

\begin{tabular}{lcccc}
\hline Country & $\begin{array}{c}\text { Pillar 12 } \\
\text { (Innovation }\end{array}$ & $\begin{array}{c}\text { Capacity for } \\
\text { innovation }\end{array}$ & $\begin{array}{c}\text { Quality of } \\
\text { scientific } \\
\text { research } \\
\text { institutions }\end{array}$ & $\begin{array}{c}\text { University- } \\
\text { industry } \\
\text { collaboration } \\
\text { in R\&D }\end{array}$ \\
\hline Serbia & 95 & 117 & 47 & 95 \\
Croatia & 106 & 120 & 66 & 118 \\
Hungary & 62 & 96 & 34 & 68 \\
Bosnia and & 123 & 132 & 106 & 111 \\
Herzegovina & 91 & 87 & 76 & 91 \\
Montenegro & 96 & 109 & 57 & 97 \\
Romania & 68 & 56 & 59 & 74 \\
Bulgaria & & & & \\
\hline
\end{tabular}

Note.Retrieved from The Global Competitiveness Report 2017/2018.

Observing the selected countries in the environment, it can be noticed that, for most innovation parameters, Serbia is poorly ranked. Namely, only Croatia, Bosnia and Herzegovina and Romania have achieved a worse position, observing the overall innovation, capacity for innovation and universityindustry collaboration in R\&D. However, it is important to note that the quality of scientific-research institutions is highly ranked when it comes to the Republic of Serbia. If we look at the previous period, the data on innovation rankings are SCHOOL OF BUSINESS, 2/2018, 12-30 
16 | ENTREPRENEURIAL INTENTIONS OF STUDENTS OF HIGHER VOCATIOANL SCHOOLS ON THE TERRITORY OF AUTONOMUS PROVINCE OF VOJVODINA

encouraging, because the Republic of Serbia has achieved a significant growth of all observed parameters that constitute innovation.

These data point to the importance of education and the need for continuous university-industry collaboration in R\&D cooperation. Youth entrepreneurship and the collaboration of the education system and the industry will influence the creation of an entrepreneurial culture and the growth of innovation in a timely manner.

Table 2

Overview of certain rankings of Serbia in the Global Competitiveness Report from 2013 to 2018

\begin{tabular}{|c|c|c|c|c|c|c|}
\hline Country & Observed rankings & 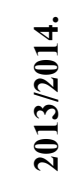 & 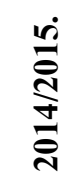 & 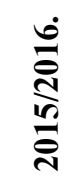 & 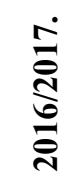 & $\frac{\infty}{\stackrel{\infty}{\sigma}}$ \\
\hline \multirow{3}{*}{ Serbia } & Global Competitiveness Index & 101 & 94 & 94 & 90 & 78 \\
\hline & & 120 & 121 & 120 & 73 & 86 \\
\hline & Venture capital availability & 129 & 132 & 130 & 104 & 95 \\
\hline
\end{tabular}

Note. Retrieved from The Global Competitiveness Report 2013/2014, 2014/2015, 2015/2016, 2016/2017, 2017/2018. Number of surveyed countries by periods: 20132014 (148), 2014-2015 (144), 2015-2016 (140), 2016-2017 (138), 2017-2018 (137)

According to the Global Competitiveness Report 2017-2018, considering Ease of Access to Loans, the Republic of Serbia is ranked 86th out of 137 countries surveyed, while regarding the possibility of venture financing it comes 95 th. Based on Table 2, it can be concluded that there is a slight improvement in the general competitiveness level, as well as ranks related to access to funding sources. The ranking of the possibility of venture financing shows an improvement from 2016/2017 but it still shows low level of capital financing opportunities and attracting private capital. All this points to the difficulty of financing companies in Serbia, especially entrepreneurs who have additional limitations.

Entrepreneurs are faced with high interest rates and difficult access to medium and long-term funding sources. However, the level of knowledge about financial management in the enterprises itself is unsatisfactory, which significantly complicates cooperation with financial institutions, because entrepreneurs are not able to present their investment projects in the right way to banks. 


\section{ENTREPRENEURIAL INTENTIONS}

The intention can be defined as a cognitive state that exists just before conducting certain type of behavior (Fayolle and Gailly, 2004; Krueger, 2003), and as a specific tendency of an individual to carry out an action or series of actions, which stems from a conscious attitude that guides behavior (Parker, 2004). Bird (1988) sees entrepreneurial intentions as a key element in understanding the process of creating a new business, and defines them as a state of mind that draws attention and action towards self-employment. Entrepreneurial intentions can also be seen as a commitment to starting a new job and as a predictor of a planned entrepreneurial behavior (Krueger, 1993), and as a possibility to start a new job (Uddin and Bose, 2012). According to Shapero (1982), the entrepreneurial intention stems from the perception of desirability and perception of feasibility and is influenced by the social and cultural context. Entrepreneurial intentions are seen as a key element in understanding the process of creating a new firm (Bird, 1988).

A review of professional literature points to a number of theories that explain the motivation of employees. Some authors have studied the motivation of entrepreneurs by applying some of the motivation theories (Canabal and O'Donnell, 2009). The overview of a large number of research points to the following reasons that lead to launching entrepreneurial ventures: independence desire,higher tendency towards risk, higher need for achievement, tolerance for ambiguity, high self-efficacy, locus of internal control and higher preference for innovation (Douglas and Shepherd, 1997; Reynolds, Carter, Gartner and Greene 2004; Shane, Locke and Collins, 2003; Shepherd and DeTienne, 2005, Stewar, Watson, Carland and Carland, 1999). The decision to launch an entrepreneurial venture consists of two levels, rational and motivational (Plehn Dujowich, 2010). The rational level refers to objective reasons for the adoption of the task, including environmental requirements, and the motivational level refers to subjective reasons that reflect the expectations of decision makers. The analysis of entrepreneurial behavior should include consideration of the reasons for this decision. In addition to the rational and motivational level, the decision to launch entrepreneurial venture is also influenced by psychological dimensions, such as: the need for achievement, the need for competition, the need for independence, the need for affiliation, the need for power, a tolerance for ambiguity, preferences for innovation, a willingness to take risk, proactiveness, persistence, etc. (Barba-Sanchez and Atienza-Sahukuillo, 2012; Brockhaus and Horvitz, 1986; Herron and Robinson, 1993).

A review of literature suggests that intentions play a very important role for one person to decide to open a new business. People who choose to establish their own company have certain attitudes, values, interests and talents in terms of 
18 | ENTREPRENEURIAL INTENTIONS OF STUDENTS OF HIGHER VOCATIOANL SCHOOLS ON THE TERRITORY OF AUTONOMUS PROVINCE OF VOJVODINA

entrepreneurship and are inherent in entrepreneurial intentions. Some authors pointed to the importance of cognitive variables which help to understand the personal decision to start a new business (Baron, 2004; Shaver and Scott, 1991). According to the authors, this cognitive focus provides additional insight into the complex process of entrepreneurship. The decision to become an entrepreneur is considered a voluntary and conscious process, and entrepreneurship can be seen as a process that occurs over time (Gartner, Shaver, Gatewood and Katz, 1994; Kyrö and Carrier, 2005). In this sense, the intention would be the first step of the process (Gartner, et al., 1994; Lee and Wong, 2004), or a necessary condition for carrying out entrepreneurial behavior (Bird, 1988; Boyd and Vozikis, 1994; Fayolle, Gailly and Lassas-Clerc 2006; Kolvereid, 1996; Krueger, 1993; Krueger and Casrud, 1993). Understanding entrepreneurial intentions is crucial for understanding entrepreneurship. The intention is one of the best predictors of behavior (Ajzen, 1991, 2001; Fishbein, and Ajzen, 1975). The intent to undertake entrepreneurial behavior is influenced by factors such as: needs, beliefs, values, habits and desires (Bird, 1988; Lee and Wong, 2004). Ajzen (1991) calls cognitive variables that affect the intent a motivational factor. More favorable factors increase the initial intention (Linan, 2004). Entrepreneurial intentions are influenced by situational factors (Ajzen, 1987; Boyd and Vozikis, 1994; Tubbs and Ekeberg, 1991) such as: task difficulty, time constraints, social pressure of other people (Lee and Wong, 2004). Perceptions of self-efficacy are also important for predicting entrepreneurial intentions (Krueger, Reilly and Crasrud, 2000), perceived behavioral control (Kolvereid, 1996) and their own competences perceived by entrepreneurs themselves (Chandler and Jansen, 1992).

There are six main models that explain entrepreneurial intentions: The Entrepreneurial Event Model (Shapero, 1982), The Theory of Planned Behavior (Ajzen, 1991), The Model of Entrepreneurial Attitude Orientation (Robinson, Stimpson, Huefner and Hunt, 1991), Intentional Basic Model (Krueger and Carsrud, 1993), Entrepreneurial Potential Model (Krueger and Brazeal, 1994) and The Model (Davidsson, 1995). The first model was the Entrepreneurial Event Model by Shapero (1982). This model considers the creation of a business as an event that can be explained by the interactions between initiative-taking, ability, management of the organisation, risk-taking, and relative autonomy while, according to this model, the personal choice to start a new business depends on the perceived feasibility, perceived desirability, and propensity to act. Ajzen's Theory of Planned Behavior (Ajzen, 1991) is one of the most frequently used models in the field of entrepreneurship. According to Ajzen, every behavior requires certain planning and can be foreseen with the intention of adopting this behavior. The intention is formed through three determinants: attitudes toward behavior, subjective norms and perceived behavioral control. 
Robinson and associates defined the Entrepreneurial Attitude Orientation Model (Robinson, et al., 1991) and described entrepreneurial attitudes by personality and demographic characteristics. They made an entrepreneurial attitude orientation scale that explains the prediction of relationships through four subscales (self-esteem, innovation, achievement, and personal control) and three types of reactions (cognitive, affective, and conative). According to the Intentional Basic Model (Krueger and Carsrud, 1993), starting a business is an intentional process that can be influenced by behavior and attitudes. The Entrepreneurial Potential Model (Krueger and Brazeal, 1994) is based on the Ajzen and Shapero models, and is based on corporate entrepreneurship and the organisational development. Davidsson Model (Davidsson Model, 1995) is based on the idea that entrepreneurial intentions are influenced by two elements, the current situation and beliefs that are defined by general attitudes (autonomy, change orientation, competitiveness, achievement motivation, and valuation of money) and domain attitudes (social contributions, pay-offs and know-how).

The most common variables used in describing and explaining entrepreneurial potentials are personality traits, motivation and intentions, education and the environment (Rieta-Carbonell, Pedraz-Hernández and Lara-García, 2011). Personality traits are seen as psychological traits or innate personality traits and as individual characteristics related to attitudes, motivation, acquired skills and abilities. Under personality traits, according to authors, we consider the need for achievement, the need for independence, internal control, preference for taking risks, creativity or innovative character and proactivity. Other personality traits, according to authors, include tolerance of insecurity, perceptiveness, initiative, dissatisfaction and marginalism, intuition, mistrust and leadership. Entrepreneurial motivation can be grouped into two categories: "pull and push factors" (Negut, di Comite and Neacsu, 2010; Rieta-Carbonell, et al., 2011). Pull factors are factors that attract entrepreneurs to business activity due to positive circumstances, and push factors are motives that individuals direct towards business activity due to adverse circumstances. Pull factors include earning money, independence, flexible functioning, realization of one's own goals, better development of own potentials and skills, personal and professional advancement, etc. Push factors include frustration in previous work, difficulties with professional advancement, the need to combine family and work tasks, inability to find work in the labor market, etc.

Educational and structural support factors positively influence the entrepreneurial intentions of students (Liñán, F., Rodríguez-Cohard and RuedaCantuche, 2011; Turker and Selcuk, 2008; Weerakoon and Gunatissa, 2014). Getting adequate knowledge can stimulate entrepreneurial intentions of individuals. A survey conducted in 2004 on the entrepreneurial intentions of university students in Singapore has shown that entrepreneurial intentions of 
20 | ENTREPRENEURIAL INTENTIONS OF STUDENTS OF HIGHER VOCATIOANL SCHOOLS ON THE TERRITORY OF AUTONOMUS PROVINCE OF VOJVODINA

students are influenced by gender, family experience, family business and educational level (Wang and Wong, 2004). Another survey, conducted in 2015 (Ambad and Damit, 2015) by students in Malaysia, has shown that entrepreneurial intentions of students are influenced by personal attitudes, perceived support and perceptions of behavior control. Also, entrepreneurial intentions of students are positively influenced by the locus of control, subjective norms and the need for achievement (Mat, Maat and Mohd 2015), skills and values (Linan, 2008), attitudes towards entrepreneurs, entrepreneurial activities and their social function (Veciana, Aponte and Urbano, 2005). Female students, in much lesser degree, compared to male students, are considering the possibility of starting their own business (Sánchez-Escobedo and FuentesGarcia 2013).

\section{RESEARCH}

\subsection{RESEARCH PROBLEM}

Based on the existing knowledge and research results, theresearchproblem was defined in the following way:

What are the entrepreneurial intentions of students of higher vocational schools on the territory of AP Vojvodina?

The problem defined in this way is scientifically valid and important, because it talks about the potentials of students of higher vocational schools to start entrepreneurial ventures. Determining entrepreneurial intentions will indicate the existence of students' wishes and intentions to start and run their own business.

\subsection{RESEARCH OBJECTIVES}

Based on the previously defined research problem, the research objectives are defined as follows:

1. Identify entrepreneurial intentions among students of higher vocational schools on the territory of AP Vojvodina.

2. Based on the obtained results and the available knowledge from the previous research, provide general guidelines and practical solutions for developing and fostering entrepreneurial intentions among students of higher vocational schools.

The incentive for writing this paper and dealing with this topic came from the fact that so far in our country the entrepreneurial intentions of students of higher vocational schools have not been examined. Given that students enrolling vocational schools are more oriented towards practical work, and that 
vocational schools themselves within their curricula foster entrepreneurship, it is considered relevant to test entrepreneurial potential with these students. The basic idea is to find out in this way the information that is important for creating favorable and incentive conditions for developing the idea, its implementation and the development of a successful company.

\subsection{RESEARCH HYPOTHESIS}

Based on the theoretical knowledge, as well as on the basis of the research that have been carried out so far, we assume that there are entrepreneurial intentions of students of higher vocational schools. The main hypothesis of this research is:

H1: Entrepreneurial intentions are present among students of higher vocational schools on the territory of AP Vojvodina.

\subsection{METHODOLOGY}

Within the framework of a project approved and financed by the Provincial Secretariat for Higher Education and Scientific Research, and for the purpose of testing the entrepreneurial potential of students of higher vocational schools on the territory of the AP Vojvodina, a questionnaire, consisting of both open and closed question, was taken and adapted from by Liñán, Rodríguez-Cohard AND Rueda-Cantuche (2011). A detailed process of creating and validating the Entrepreneurial Intention Questionnaire (EIQ) was explained in Liñán and Chen (2009) and validated in research of Kolvereid (1996), Krueger et al. (2000) and Veciana et al. (2005). The sample includes 442 students of vocational schools from the territory of AP Vojvodina. The following schools participated in the study:

- College of Applied Studies in Management and Business Communication in Sremski Karlovci

- Preschool Teacher Training and Business Informatics College of Applied Studies - Sirmium inSremska Mitrovica

- Novi Sad School of Business

- Higher Agricultural School of Vocational Studies in Šabac

- The Higher Education Technical School of Professional Studies in Novi Sad

- Technical College of Applied Studies 
22 | ENTREPRENEURIAL INTENTIONS OF STUDENTS OF HIGHER VOCATIOANL SCHOOLS ON THE TERRITORY OF AUTONOMUS PROVINCE OF VOJVODINA

Table 3

The structure of respondents by institutions

\begin{tabular}{|c|c|c|c|c|}
\hline & Frequencies & Percentages & $\begin{array}{c}\text { Valid } \\
\text { percetages }\end{array}$ & $\begin{array}{c}\text { Cummulative } \\
\text { percentages }\end{array}$ \\
\hline $\begin{array}{l}\text { College of Applied Studies in } \\
\text { Management and Business } \\
\text { Communication - Sremski } \\
\text { Karlovci }\end{array}$ & 31 & 7,0 & 7,0 & 7,0 \\
\hline $\begin{array}{l}\text { Preschool Teacher Training } \\
\text { and Business Informatics } \\
\text { College of Applied Studies } \\
\text { Sirmium - Sremska Mitrovica }\end{array}$ & 106 & 24,0 & 24,0 & 31,0 \\
\hline Novi Sad School of Business & 114 & 25,8 & 25,8 & 56,8 \\
\hline $\begin{array}{l}\text { Higher Agricultural School of } \\
\text { Vocational Studies - Śabac } \\
\text { The Higher Education }\end{array}$ & 79 & 17,9 & 17,9 & 74,7 \\
\hline $\begin{array}{l}\text { Technical School of } \\
\text { Professional Studies - Novi } \\
\text { Sad }\end{array}$ & 90 & 20,4 & 20,4 & 95,1 \\
\hline $\begin{array}{l}\text { Technical College of Applied } \\
\text { Studies - Zrenjanin }\end{array}$ & 22 & 4,9 & 4,9 & 100,0 \\
\hline Total & 442 & 100,0 & 100,0 & \\
\hline
\end{tabular}

Note: Calculated by the authors.

\section{RESULTS}

A preliminary analysis was conducted for the four observed variables: I am determined to open my own business in the future, The estimated time that will pass between your graduation and starting your own business, With whom you would like to start your job and Where do you see yourself after completing the studies.

The variable examined whether students were determined to start up their own business the future. Most students want to open their company in the future (24.9\%) and feel that they will do their best to start and run their own business. 
Table 4

Frequency for the variable "I am determined to open my own business in the future"

\begin{tabular}{llcccc}
\hline & Frequencies & Percents & $\begin{array}{c}\text { Valid } \\
\text { percents }\end{array}$ & $\begin{array}{c}\text { Cummulative } \\
\text { percent }\end{array}$ \\
\hline \multirow{6}{*}{ Valid } & & & 17,6 & 17,7 & 17,7 \\
& I totally disagree & 78 & 15,4 & 15,4 & 33,1 \\
& I disagree & 68 & 21,7 & 21,8 & 54,9 \\
& I am not sure & 96 & 20,1 & 20,2 & 75,1 \\
& I agree & 89 & 24,9 & 24,9 & 100,0 \\
& I totally agree & 110 & 99,8 & 100,0 & \\
& Total & 441 & \multicolumn{3}{c}{} \\
\hline Missing & 1 & \multicolumn{3}{c}{} &
\end{tabular}

Note: Calculated by the authors.

Table 5

Frequences for the variable "The estimated time that will pass between your graduation and starting your own business"

\begin{tabular}{|c|c|c|c|c|c|}
\hline & & Frequencies & Percents & $\begin{array}{c}\text { Valid } \\
\text { percents }\end{array}$ & $\begin{array}{c}\text { Cummulative } \\
\text { percents }\end{array}$ \\
\hline \multirow{7}{*}{ Valid } & 1 I have no intention & 89 & 20,1 & 20,2 & 20,2 \\
\hline & $\begin{array}{l}2 \text { after completing } \\
\text { my studies }\end{array}$ & 65 & 14,7 & 14,8 & 35,0 \\
\hline & 31 to 2 & 82 & 18,6 & 18,6 & 53,6 \\
\hline & 43 to 5 & 114 & 25,8 & 25,9 & 79,5 \\
\hline & 5 more than 5 & 89 & 20,1 & 20,2 & 99,8 \\
\hline & 34 & 1 & , 2 &, 2 & 100,0 \\
\hline & Total & 440 & 99,5 & 100,0 & \\
\hline \multirow[t]{2}{*}{ Missing } & & 2 &, 5 & & \\
\hline & Total & 442 & 100,0 & & \\
\hline
\end{tabular}

Note: Calculated by the authors.

The variable examined expected time that would pass between the completion of studies and the establishment of one's own business. The largest number of students answered that the estimated time between finishing studies and establishing their own job is from 3 to 5 years (25.9\%). 20.2\% of students answered that theestimated time between completing studies and setting up their own business is more than 5 years, and the same percentage of students replied that they have no intention to start his own business. $14.8 \%$ of students answered that they would start their own work immediately after completing their studies.18.6\% of students said they would begin their work one to two years after completing their studies. 
24 | ENTREPRENEURIAL INTENTIONS OF STUDENTS OF HIGHER VOCATIOANL SCHOOLS ON THE TERRITORY OF AUTONOMUS PROVINCE OF VOJVODINA

Table 6

Frequency for variable "With whom would you like to start your job?"

\begin{tabular}{llcccc}
\hline & Frequences & Percents & $\begin{array}{c}\text { Valid } \\
\text { percents }\end{array}$ & $\begin{array}{c}\text { Cummulative } \\
\text { percents }\end{array}$ \\
\hline \multirow{6}{*}{ Validni } & 1 I have no intention & 74 & 16,7 & 16,8 & 16,8 \\
& 2 on my own & 137 & 31,0 & 31,1 & 47,8 \\
& 3 in a team & 146 & 33,0 & 33,1 & 81,0 \\
& 4 private business & 36 & 8,1 & 8,2 & 89,1 \\
& 5 something different & 47 & 10,6 & 10,7 & 99,8 \\
& 6 & 1 &, 2 &, 2 & 100,0 \\
& Total & 441 & 99,8 & 100,0 & \\
\hline Missing & \multicolumn{5}{c}{1} \\
\hline
\end{tabular}

Note: Calculated by the authors.

It was investigated with which students would most preferably start their own business. The largest number of students answered that they would like to start their work in the team $(33.1 \%)$ or independently (31.1\%). Only $16.8 \%$ of students stated that they have no intention to start their business either independently or with someone else.

Table 7

Frequency for the variable "Where do you see yourself after completing the study?"

\begin{tabular}{|c|c|c|c|c|c|}
\hline & & Frequency & Percent & $\begin{array}{l}\text { Valid } \\
\text { Percent }\end{array}$ & $\begin{array}{c}\text { Cumulative } \\
\text { Percent }\end{array}$ \\
\hline \multirow{8}{*}{ Valid } & $\begin{array}{l}1 \text { getting employed in your } \\
\text { own country }\end{array}$ & 142 & 32,1 & 32,3 & 32,3 \\
\hline & $\begin{array}{l}2 \text { continuing studies in the } \\
\text { country }\end{array}$ & 58 & 13,1 & 13,2 & 45,5 \\
\hline & $\begin{array}{l}3 \text { starting up your own } \\
\text { business in the country }\end{array}$ & 73 & 16,5 & 16,6 & 62,0 \\
\hline & 4 going abroad for studies & 18 & 4,1 & 4,1 & 66,1 \\
\hline & $\begin{array}{l}5 \text { going abroad for } \\
\text { employment }\end{array}$ & 88 & 19,9 & 20,0 & 86,1 \\
\hline & 6 going abroad for experience & 60 & 13,6 & 13,6 & 99,8 \\
\hline & 34 & 1 & ,2 &, 2 & 100,0 \\
\hline & Total & 440 & 99,5 & 100,0 & \\
\hline \multirow[t]{2}{*}{ Missing } & & 2 &, 5 & & \\
\hline & Total & 442 & 100,0 & & \\
\hline
\end{tabular}

Note: Calculated by the authors. 
This question examined how students see their future after graduation. The highest percentage of students responded that they want employment in their country $(32.3 \%)$, while the smallest percentage of students responded that they want to go abroad to study (4.1\%). Students see their future after completing their studies in their own country.

\section{CONCLUSION}

The paper presents the results of the empirical research of 442 students from six higher vocational schools on the territory of AP Vojvodina. Given that the aim of the research was to examine the entrepreneurial intentions of students of higher vocational schools on the territory of APV, the results pointed to the existence of the desire and intention of students to start and run their own business.

The results showed that most students are determined to open their company in the future and that they will do their best to start and run their own business. Likewise, the largest number of students think that the planned time between completing studies and setting up their own work is from 3 to 5 years. Most students answered that they would like to start their business in the team. Students see their future after completing their studies in their own country, so the largest percentage of students answered that they want employment in their own country.

However, the very existence of a good business idea is not enough for its realization. The development of the idea, its implementation and the development of a successful company are the most important aspects of entrepreneurship. The role of education is of great importance, but also the connection between the educational system and the economy, which will influence the creation of an entrepreneurial culture through the growth of creativity and innovation.

Based on the above, it can be concluded that improvements are necessary in the following areas: further education of students, potential entrepreneurs, both within formal education, as well as within the national support network and private consultants, improving the institutional framework and improving the business environment for performing entrepreneurial activity and improving financial support.

\section{REFERENCE}

Ambad, S.N.A., \& Damit, D.H.D. (2015). Determinants of Entrepreneurial Intention among UndergraduateStudents in Malaysia. Procedia Economics and Finance, 37, 108-114. 
26 | ENTREPRENEURIAL INTENTIONS OF STUDENTS OF HIGHER VOCATIOANL SCHOOLS ON THE TERRITORY OF AUTONOMUS PROVINCE OF VOJVODINA

Ajzen, I. (1987). Attitudes, traits, and actions-Dispositional prediction of behavior in personality andsocial-psychology. Advances in Experimental Social Psychology, 20, 1-63.

Ajzen, I. (1991). The theory of planned behavior. Organizational Behavior and Human Decision Processes, 50, 179-211.

Ajzen, I. (2001). Nature and operation of attitudes. Annual Review of Psychology, 52, 27-58.

Barba-Sánchez, V., \& Atienza-Sahuquillo, C. (2012). Entrepreneurial behavior: Impact of motivation factors on decision to create a new venture. Investigaciones Europeas de Dirección y Economia de la Empresa, 18, 132-138.

Baron, R.A. (2004). The cognitive perspective: A valuable tool for answering entrepreneurship's basic “why” questions. Journal of Business Venturing, 19(2), 221-239.

Bird, B. (1988). Implementing entrepreneurial ideas: the case for intention. Academy of Management Review, 13(3), 442-453.

Boyd, N.G. \& Vozikis, G.S. (1994). The influence of self-efficacy on the development of entrepreneurialintentions and actions. Entrepreneurship Theory and Practice, 18, 63-77.

Brockhaus, R.H., \& Horwitz, P.S. (1986). The psychology of the entrepreneur. In: Sexton, D.L. and Smilor, R.W. (Eds.), The art and science of entrepreneurship (25-48). Cambridge: Ballinger.

Canabal, A., \& O'Donnell, E. (2009). It's not only about what you want, but also how much you want it: Developing a new theoretical perspective on entrepreneurial motivation. Frontiers of Entrepreneurship Research, 29, 130.

Chandler, G.N., \& Jansen, E. (1992). The founder's self-assessed competence and venture performance. Journal of Business Venturing, 7(3), 223.

Davidsson, P. (1995). Culture, structure and regional levels of entrepreneurship. Entrepreneurship and Regional Development, 7, 41-52.

Davidsson, P. (1995). Determinants of entrepreneurial intentions. Paper presented at the annual meeting of the Rent IX Workshop, Piacenza Italy (November).

Douglas, E.J., \& Shepherd, D.A. (1997). Why entrepreneurs create businesses: a utility maximizing response. Frontiers of Entrepreneurship Research, 17, 185-186.

Eurostat (2018). Main statistical findings, SMEs in the Non-financial business economy, Retrieved from: http://ec.europa.eu/eurostat/statisticsexplained/index.php/Business_economy_-_size_class_analysis, 17.07.2018. 
Fayolle, A., \& Gailly, B. (2004). Using the theory of planned behaviour to assess entrepreneurship teaching programs: a first experimentation, In IntEnt2004 Conference. Naples (Italy).

Fayolle, A., Gailly, B., \& Lassas-Clerc, N. (2006). Assessing the impact of entrepreneurship education programmes: A new methodology. Journal of European Industrial Training, 30(9), 701-720.

Fishbein, M. \& Ajzen, I. (1975). Belief, attitude, intention and behavior: An introduction to theory and research. New York: Addison-Wesley.

Gartner,W.B., Shaver, K.G., Gatewood, E.J., \& Katz, J. (1994). Finding the entrepreneur in entrepreneurship. Entrepreneurship Theory and Practice, 18(3), 5-10.

GEM, Global Entrepreneurship Monitoring, 2015/2016, Retrieved from: http://www.gemconsortium.org/report/49480, 18.07.2018.

Herron, L., \& Robinson, R.B. (1993). A structural model of the effects of entrepreneurial characteristics on venture performance. Journal of Business Venturing, 8, 281294.

Jovin, S., Papić-Blagojević, N., Jošanov-Vrgović, I., \& Jovičić Vuković, A. (2018). Faktori razvoja preduzetničkih kreativnih ideja studenata visokih strukovnih škola. U: XXIV skup Trendovi razvoja. Kopaonik.

Jošanov- Vrgović, I., Jovin, S., Papić-Blagojević, N., \& Jovičić Vuković, A. (2017). Inovacioni potencijal i preduzetništvo - empirijska analiza studenata visokih strukovnih škola. U: Inovacijama do održivog razvoja. Beograd, Republika Srbija: Fakultet za primenjeni menadžment, ekonomiju i finansije.

Kolvereid, L. (1996). Prediction of employment status choice intentions. Entrepreneurship Theory and Practice, 21(1), 47-57.

Krueger, N. F. (1993). The impact of prior entrepreneurial exposure on perceptions of new venture feasibility and desirability. Entrepreneurship Theory and Practice, 18(1), 5-21.

Krueger, N. F., \& Carsrud, A. L. (1993). Entrepreneurial intentions: Applying the theory of planned behavior. Entrepreneurship and Regional Development, 5(4), 315-330.

Krueger, N. F., \& Brazeal, D. (1994). Entrepreneurial potential and potential entrepreneurs. Entrepreneurship Theory and Practice, 18(3), 91-104.

Krueger, N.F., Reilly, M.D., \& Carsrud A.L. (2000). Competing models of entrepreneurial intentions. Journal of Business Venturing, 15(5-6), 411432.

Krueger, N. F. (2003). The Cognitive Psychology of Entrepreneurshipll, in Acs, Z. J. and Audretsch, D. B. (eds.), Handbook of entrepreneurship research: An interdisciplinary survey and introduction, Kluwer, London, 105-140. 
28 | ENTREPRENEURIAL INTENTIONS OF STUDENTS OF HIGHER VOCATIOANL SCHOOLS ON THE TERRITORY OF AUTONOMUS PROVINCE OF VOJVODINA

Kyrö, P. \& Carrier, C. (2005). Entrepreneurial learning in universities: Bridges across borders. In P. Kyrö \& C. Carrier (Eds.), The dynamics of learning entrepreneurship in a cross-cultural university context (pp. 14-43). Hämmeenlinna: University of Tampere.

Lee, S.H. \& Wong, P.K. (2004). An exploratory study of technopreneurial intentions: A career anchor perspective. Journal of Business Venturing, 19(1), 7-28.

Liñán, F. (2008).Skill and value perceptions: how do they affectentrepreneurial intentions?International Entrepreneurship and Management Journal, 4, 257-272.

Liñán, F. (2004). Intention-based models of entrepreneurship education. Piccola Impresa/Small Business, 3, 11-35.

Liñán, F., Rodríguez-Cohard, J., \& Rueda-Cantuche, J. (2011). Factors Affecting Entrepreneurial Intentions Levels: A Role for Education. International Entrepreneurship and Management Journal, 7(2), 195-218.

Liñán, F., \& Chen, Y.W. (2009). Development and Cross-Cultural Application of a Specific Instrument to Measure Entrepreneurial Intentions. Entrepreneurship Theory and Practice, 33(3), 593-617.

Mat, S.C., Maat, S.M., \& Mohd, N. (2015). Identifying Factors that Affecting the Entrepreneurial Intentionamong Engineering Technology Students. Procedia - Social and Behavioral Sciences, 211,1016-1022.

Ministarstvo privrede, Ministarstvo regionalnog razvoja i lokalne samouprave, Nacionalna agencija za regionalni razvoj (2013). Izveštaj o MSPP za 2012. godinu, Beograd.

Negut, S., di Comite, L., \& Neacsu, M.C. (2010). Immigration - Socioeconomical Implications. The Case of Romania. Amfiteatru Economic, 12(28), 576-593.

Parker, S. C. (2004). The economics of self-employment and entrepreneurship. Cambridge University Press.

Plehn Dujowich, J. (2010). A theory of serial entrepreneurship. Small Business Economics, 35, 377-398.

Privredni forum mladih (2016). Analiza rezultata istraživanja o potrebama potencijalnih i postojećih mladih preduzetnika u Republici Srbiji.

Reynolds, P.D., Carter, N.M., Gartner, W.B., \& Greene, P.G. (2004). The Prevalence of Nascent Entrepreneurs in the United States: Evidence from the Panel Study of Entrepreneurial Dynamics. Small Business Economics, 23, 263-284.

Rieta-Carbonell, J., Pedraz-Hernández, J. C., \& Lara-García, F. J. (2011). Business creation by immigrant entrepreneurs in valencian community. The influence of education. International Entrepreneurship and Management Journal, 10(2), 409-426. 
Robinson, P. B., Stimpson, D., Huefner, J. C., \& Hunt, H. K. (1991). An attitude approach to the prediction of entrepreneurship. Entrepreneurship Theory and Practice, 15(4), 13-31.

Sánchez-Escobedo, M. C., Díaz-Casero, J. C., Hernández-Mogollón, R., \& Postigo-Jiménez, M. V. (2011). Perceptions and attitudes towards entrepreneurship. an analysis of gender among university students. International Entrepreneurship and Management Journal, 7, 443-463.

Sánchez-Escobedo, M. C., Fuentes-Garcia, F. (2013). Gender and Entrepreneurship: Analysis of a young University Population. Regional and Sectoral Economic Studies, 13(1), 65-78.

Shane, S., Locke E. A., \& Collins, C.J. (2003). Entrepreneurial Motivation. Human Resource Management Review, 13, 257-279.

Shapero, A., \& Sokol, L. (1982). Social dimensions of entrepreneurship. In: C. A. Kent et al. (Eds.), The encyclopaedia of entrepreneurship (pp. 72-89). Englewood Cliffs, NJ: Prentice-Hall.

Shaver, K.G. \& Scott, L.R. (1991). Person, process, choice: The psychology of new venture creation. Entrepreneurship Theory and Practice, 16(2), 2345.

Shepherd, D.A., \& Detienne, D.R. (2005). Prior Knowledge, Potential Financial Reward, and Opportunity Identification. Entrepreneurship Theory \& Practice, 29, 91-112.

Stanković, Lj., Đukić, S., \& Lepojević, V. (2014). Innovation capacities of Serbian Small and medium-sized enterprises. Teme, 3/2014, 1077-1093.

Stewart, W.H. Jr., Watson, W.E., Carland, J.C., \& Carland, J.W. (1999). A proclivity for entrepreneurship: a comparison of entrepreneurs, small business owners, and corporate managers. Journal of Business Venturing, 14, 189-214.

The World Economic Forum. The Global Competitiveness Report 2013/2014, The Global Competitiveness Report 2014/2015, The Global Competitiveness Report 2015/2016, The Global Competitiveness Report 2016/2017 and The Global Competitiveness Report 2017/2018.

Tubbs, M.E. \& Ekeberg, S.E. (1991). The role of intentions in work motivation: Implications for goal-settingtheory and research. Academy of Management Review, 16(1), 180-199.

Turker, D., \& Selcuk, S.S. (2008). Which factors affectentrepreneurial intention ofuniversity students?Journal of European Industrial Training, 33(2), 142-159.

Uddin, M. R., \& Bose, T. K. (2012). Determinants of entrepreneurial intention of business students in Bangladesh. International Journal of Business and Management, 7(24), 128-137. 
30 | ENTREPRENEURIAL INTENTIONS OF STUDENTS OF HIGHER VOCATIOANL SCHOOLS ON THE TERRITORY OF AUTONOMUS PROVINCE OF VOJVODINA

Veciana, J.M., Aponte, M., \& Urbano, D. (2005). University Students' Attitude Towards Entrepreneurship: A Two Countries Comparison. International Entrepreneurship and Management Journal, 1, 2, 165-182.

Wang, C.K., \& Wong, P.K. (2004). Entrepreneurial interest of university students in Singapore. Technovation, 24(2), 163-172.

Weerakoon, W.M.P.G.C., \& Gunatissa, H.H.A.J. (2014). Antecedents of of Entrepreneurial Intention (With Reference to Undergraduates of UWU, Sri Lanka). International Journal of Scientific and Research Publications, 4(11), 1-6.

Delivered: 05.12.2018. Accepted: 10.02.2019.

Note: The results presented in this paper are a part of the results of the project financed by the Provincial Secretariat for Higher Education and Scientific Research. The project entitled "Entrepreneurial Potential of Students of Higher Vocational Schools in the Autonomous Province of Vojvodina" was approved on June 12, 2017, decision number 142-4512814/2017-02-1. 